KINGA MAJCHRZAK

Uniwersytet Mikotaja Kopernika

$w$ Toruniu

\title{
MIEJSCA PAMIĘCI W EDUKACJI OBYWATELSKIEJ
}

ABSTRACT. Majchrzak Kinga, Miejsca pamięci w edukacji obywatelskiej [Memorial Sites in Civic Education]. Studia Edukacyjne nr 42, 2016, Poznań 2016, pp. 251-262. Adam Mickiewicz University Press. ISSN 1233-6688. DOI: $10.14746 /$ se.2016.42.15

The text starts with a short introduction. Then the concept of place is defined and its inherent characteristics are described: its symbolism, multi-sided nature and multidisciplinary connotations. Afterwards the principles of place-based pedagogy are presented and it's eclectic character is pointed out. Then, attempt explain idea of the memorial sites from the standpoint of history and pedagogy. In the final part the author relates to educational potential of (national) memorial sites and takes a stance on the role of memorial sites in citizenship education.

Key words: place, pedagogy of place, memorial sites, civic education, civic competences, historical thinking

Człowiek epoki globalnej jest skoncentrowany na sobie. Uparcie poszukując własnej tożsamości, coraz częściej zapomina o wspólnotowości i daleki jest od kwestionowania dychotomii: państwowe - prywatne. Katalizatorami dla tego typu zachowań są atrybuty współczesności: „natychmiastowość”, zmienność, czy też relatywizm¹, które prowadzą do "prywatyzacji życia”2 oraz sprzyjają alienacji społecznej i indywidualizacji prowadzącej do egotycznej dbałości o własny komfort nawet kosztem innych. W tym kontekście ważne jest uświadomienie jednostce, że jest częścią demokratycznej społeczności, która wymaga od obywateli postawy zaangażowanej, dokonywa-

1 Z. Melosik, Kultura instant - paradoksy pop-tożsamości, [w:] Pedagogika u progu trzeciego tysiaclecia, red. A. Nalaskowski, K. Rubacha, Torun 2001, s. 31-47.

2 Z. Bauman, Więc będzie wojna? "Gazeta Wyborcza” z 14-15 kwietnia 2012, s. 17. 
nia świadomych wyborów oraz generowania poczucia odpowiedzialności za dobro wspólne.

Celem niniejszego artykułu jest ukazanie możliwości wykorzystania miejsc pamięci w edukacji obywatelskiej, rozumianej jako proces dostarczania niezbędnej wiedzy, kształtowania wartościowych postaw i wyposażenia $\mathrm{w}$ umiejętności umożliwiające sprawne działanie $\mathrm{w}$ ramach demokratycznego społeczeństwa ${ }^{3}$. Tematyka ta wydaje się szczególnie istotna, biorąc pod uwagę problem deficytu obywatelskości w Polsce 4 .

W tekście zaprezentowano definicje miejsca oraz odniesiono się do kategorii miejsca $\mathrm{w}$ rozważaniach pedagogicznych. Zajęto także stanowisko wobec kluczowych założeń pedagogiki miejsca, podkreślając przy tym jej multidyscyplinarność, empiryczność i eksperymentalność. Podjęto próbę wyjaśnienia terminu miejsce pamięci, a także ukazano konteksty edukacyjne, w jakich funkcjonują miejsca pamięci. W finalnej części artykułu poddano analizie tematykę potencjału edukacyjnego miejsc pamięci w kształtowaniu kompetencji obywatelskich.

\section{Miejsce w pedagogice}

Za aforystyczną definicję pojęcia miejsce, bazującą na opozycyjności względem przestrzeni, uznać można słowa Yi-Fu Tuana, utożsamiające miejsce $\mathrm{z}$ bezpieczeństwem, do którego jesteśmy przywiązani, a przestrzeń z utęsknioną wolnością5. Nawiązują do niej w swoich rozważaniach Maria Mendel ${ }^{6}$ oraz Henryka Kwiatkowska, według której

miejsce (...) jest uporządkowaną strukturą znaczeń. Mówiąc inaczej „miejsca nie są neutralnymi i obiektywnymi segmentami przestrzeni fizycznej, lecz terenem specyficznie ludzkiego zaangażowania". (...) Miejsca są darem, azylem zwłaszcza na trudny czas, są źródłem sensu?.

${ }^{3}$ M. Simlat, Edukacja obywatelska jako ksztattowanie kompetencji obywatelskich, [w:] Edukacja w społeczeństwie obywatelskim i system wartości, red. J. Żebrowski, Gdańsk 1996, s. 68.

${ }^{4}$ K. Przyszczypkowski, Postawy obywatelskie Polaków. Studium empiryczne, [w:] Wychowanie obywatelskie. Studium teoretyczne, porównawcze i empiryczne, red. Z. Melosik, K. Przyszczypkowski, Torun - Poznań 1998, s. 125; H. Solarczyk-Szwec, Edukacja obywatelska młodzieży i dorostych wobec przemocy politycznej - działania na pograniczu aktywności społecznej, oświatowej i kulturalnej, Rocznik Andragogiczny, 2007, s. 185.

${ }^{5}$ Y. Tuan, Przestrzeń i miejsce, Warszawa 1987, s. 13.

${ }^{6}$ M. Mendel, Pedagogika miejsca i animacja na miejsce wrażliwa, [w:] Pedagogika miejsca, red. M. Mendel, Wrocław 2006, s. 26.

${ }^{7}$ H. Kwiatkowska, Czas, miejsce, przestrzeń - zaniedbane kategorie pedagogiczne, [w:] Pedagogika u progu trzeciego tysiąclecia, red. A. Nalaskowski, K. Rubacha, Toruń 2001, s. 64. 
Nie tylko dla H. Kwiatkowskiej miejsce jest fragmentem przestrzeni, z którym na drodze refleksyjnej interpretacji jednostka się utożsamia. Również Ewa Kurantowicz, według której miejsce to „ (...) przestrzeń uświadamiana i doświadczana"8, dostrzega niniejszą prawidłowość.

Przywołane definicje oscylują wokół dwóch immanentnych właściwości miejsca pozostających ze sobą $\mathrm{w}$ nierozerwalnym związku: symboliczności oraz wzajemnym oddziaływaniu na siebie miejsc i jednostek, które nadają im znaczenie ${ }^{9}$. Podkreślają one również, iż czynnikiem decydującym o wyodrębnieniu danego miejsca z przestrzennego bezkresu jest jego wieloaspektowa istota. Miejsce nie jest bowiem wyłącznie materialnym składnikiem przestrzeni, ale przede wszystkim ma wymiar semiotyczny, który można rozpatrywać zarówno na poziomie jednostki, jak i społeczeństwa ${ }^{10}$. Wymienione cechy miejsca przemawiają na korzyść tezy, iż miejsce może "(..) pobudzić prawdziwą pasję pedagogicznego działania"11.

Maria Mendel zauważa, iż

pedagogikę miejsca tworzy wraz z ontologicznym myśleniem o miejscu bezmiar możliwości edukacyjnych. Możliwości oddziaływania nie tylko „bezpośrednio” na wychowanka, ale wchodzenie $\mathrm{z}$ nim $\mathrm{w}$ interakcje wychowawcze poprzez miejsca, w których one zachodząi2.

Zdaniem badaczki, sam proces kreowania miejsca, w którym odbywa się akt edukacyjny, nosi znamiona wychowania. Twierdzi ona również, że miejsce można rozumieć $\mathrm{w}$ sposób podmiotowy, przypisać mu rolę wychowawcy "(...) i mówić o »miejscu wychowującym «"13. Parafrazowane słowa pokazują, iż miejsce może być aktywnym uczestnikiem, a nawet sprawcą wychowania. Jednostka, która znajdzie się w miejscu o określonych właściwościach może doznać swoistego katharsis, zweryfikować dotychczasowy system wartości lub utwierdzić się w nim. Dlatego, pedagogiczne rozważania na temat miejsca powinny wykraczać poza utożsamianie go z niemym świadkiem działań edukacyjnych.

${ }^{8}$ E. Kurantowicz, Uczenie się dorostych przez „biografię miejsca”, Dyskursy Młodych Andragogów, 2003, 4, s. 96.

${ }^{9}$ E.T. Hall, Ukryty wymiar, Warszawa 1978, s. 148; M. Mendel, Wstęp, [w:] Pedagogika miejsca, s. 9-10; I. Sagan, Ludzie i ich miejsca w geografii postmodernistycznej, [w:] Różnica, tożsamość, edukacja. Szkice z pogranicza, red. T. Szkudlarek, Kraków 1995, s. 147.

10 S.R. Jayanandhan, John Dewey and a pedagogy of place, Philosophical Studies in Education, 2009, 40, s. 104.

11 M. Mendel, Wstęp, [w:] Pedagogika miejsca, s. 26.

12 Tamże.

13 Tamże. 
Teoretycy pedagogiki miejsca podkreślają, iż rozumienie tej subdyscypliny pedagogiki wyłania się z poszczególnych atrybutów miejsca, zakotwiczonych m.in. w geografii, historii, socjologii, czy ekologii. Akcentują oni interdyscyplinarność, empiryczność i eksperymentalność omawianej dziedziny wiedzy, nie zapominając, iż odnosi się do problematyki wykraczającej poza edukację zorientowaną na rynek pracy ${ }^{14}$. Oznacza to, że pedagogika miejsca charakteryzuje się teoretycznym eklektyzmem i refleksyjnością. Cechy te umożliwiają jej wnikliwą analizę potencjału edukacyjnego miejsca, który został dostrzeżony przez Aleksandra Nalaskowskiego, utrzymującego, iż $\mathrm{w}$ rozważaniach nad procesem uczenia się nie należy pomijać miejsca, w którym się on odbywa ${ }^{15}$ oraz Romana Schulza, stojącego na stanowisku, że „(...) analiza semiotyczna architektury obiektów szkolnych wniosłaby do naszej wiedzy o wychowaniu więcej niż niejeden współczesny podręcznik pedagogiki"16.

Pedagogika miejsca jest stosunkowo nową subdyscypliną pedagogiczną. Jednakże tematyka miejsca była obecna $\mathrm{w}$ rozważaniach pedagogów od dawna, czego dowodzi fakt występowania jej założeń w innych koncepcjach edukacyjnych. Według Davida A. Grunewalda, cele i praktyka edukacji zorientowanej na miejsce mogą być powiązane $\mathrm{z}$ uczeniem się eksperymentalnym, uczeniem problemowym, edukacją pozaszkolną (poza murami szkoły), edukacją środowiskową i ekologiczną, uczeniem się kontekstualnym, edukacją bio-regionalną, edukacją demokratyczną, edukacją multikulturalną, edukacją zorientowaną na wspólnotę lokalną oraz z inni nurtami dotyczącymi kontekstu i wartości uczenia się specyficznych miejsc, a także pielęgnowania ich, tak jak i wspólnot lokalnych czy regionów ${ }^{17}$. W opinii Małgorzaty Zielińskiej, zaprezentowaną listę należy uzupełnić o „(...) uczenie się przez biografie miejsca Ewy Kurantowicz (2003), edukację regionalną czy wszelką edukację do lokalności"18. Analiza przytoczonych słów pozwala wnioskować, iż w przypadku pedagogiki miejsca, która zajmuje się bardzo szerokim i znaczącym obszarem badawczym, praktyka wyprzedziła teorię.

Podsumowując powyższe rozważania, należy zaakcentować wielowymiarowość miejsca, które dzięki swojej złożonej istocie może być zarówno

14 D.A. Grunewald, The Best of Both Worlds: A Critical Pedagogy of Place, Educational Researcher, 2003, 4(32), s. 7; C.L. Knapp, Woodhouse, http://www.ericdigests.org/20013/place.htm [dostęp: 19.11.2011].

15 A. Nalaskowski, Przestrzenie i miejsca szkoty, Kraków 2002, s. 9.

16 R. Schulz, Wykłady z pedagogiki ogólnej. Perspektywy światopogladowe w wychowaniu, Torun 2003, s. 47.

17 D.A. Grunewald, The Best of Both Worlds, s. 3.

${ }_{18}$ M. Zielińska, Edukacja dorostych imigrantów na Islandii w świetle pedagogiki miejsca, Rocznik Andragogiczny, 2009, s. 360. 
obszarem edukacji formalnej, jak i pozaformalnej, edukacji skierowanej nie tylko do dzieci, ale także do osób dorosłych. Przede wszystkim, symboliczna natura miejsca może stać się inspiracją do autorefleksji, impulsem do dalszych poszukiwań i samowychowania ${ }^{19}$, które nabiera szczególnego znaczenia w warunkach demokratycznego społeczeństwa. Janice L. Woodhouse i Clifford L. Knapp zaznaczają, że powodem rozwijania perspektywy edukacji opartej na miejscu jest skuteczne dostarczenie za jej pomocą wiedzy i doświadczenia potrzebnego do aktywnego uczestnictwa w procesie demokratycznym, możliwość wykorzystania jej na potrzeby edukacji obywatelskiej i ekologicznej ${ }^{20}$. A zatem, pedagogika miejsca cechuje się także społecznym ukierunkowaniem.

\section{Miejsce pamięci w historii}

Literatura historyczna zawiera liczne próby zdefiniowania pojęcia miejsce pamięci, które wskazują na wieloaspektowość omawianej problematyki. Beata Pinkiewicz-Gara postrzega miejsce pamięci, jako

(...) grób lub cmentarz wojenny, nieruchomość lub obiekt budowlany albo jego posiadłości, upamiętniające postaci lub wydarzenia znaczące dla narodu, w szczególności pomniki, krzyż przydrożny, kapliczka, kopiec, tablica pamiątkowa ${ }^{21}$.

Inny od tradycyjnego pogląd wyraża Joanna Górska, powołując się na myśl Pierre'a Nora: „(...) miejsca pamięci to elementy obecne w pamięci zbiorowej, które fundują tożsamość grupy i są tym samym punktami krystalizacji grupowych autodefinicji"22. Za ideowe miejsce pamięci uznać można tradycję, rozumianą zarówno $\mathrm{w}$ kategoriach regionu, grupy zawodowej, rodziny, jak $\mathrm{i}$ „(...) drobnych często niezauważalnych wydarzeń, które z czasem nabierają jakiegoś znaczenia (...)"23. Cechą wspólną definicji miejsca pamięci w historii jest pojmowanie go jako symbolu utrwalonego $\mathrm{w}$ pamięci zbiorowej i kulturowej, jako spoiwa danej społeczności²4. Tomasz Kranz podkreśla, że miejsca pamięci „pełnią (...) funkcję nośników przeszło-

${ }^{19}$ M. Mendel, Pedagogika miejsca i animacja na miejsce wrażliza, s. 27-28.

20 C.L. Knapp, Woodhouse, http://www.ericdigests.org/2001-3/place.htm, [dostęp: 19.11.2011].

${ }^{21}$ B. Pinkiewicz-Gara, Twierdza kłodzka - miejsce pamięci, [w:] Miejsca pamięci w edukacji historycznej. Zbiór studiów, red. S. Roszak, M. Strzelecka, A. Wieczorek, Torun 2009, s. 154.

22 J. Górska, Lenino - zapomniane miejsce pamięci narodowej, [w:] tamże, s. 184.

${ }^{23}$ P. Unger, Tradycja też jest miejscem pamięci, [w:] tamże, s. 197.

${ }^{24}$ S. Roszak, O miejscach pamięci, [w:] tamże, s. 7. 
ści, komponentów kultury pamięci, podmiotów komunikacji historycznej i ośrodków oddziaływania społecznego" 25 .

Rozumienie miejsc pamięci w tym tekście wykracza poza wytwory kultury materialnej. Jego osnową są wartości transcendentalne, uniwersalne, które są przeciwwagą dla czynników zakłócających proces formowania się społeczeństwa demokratycznego, stanowiącego opozycję dla tzw. „cwaniactwa"26. Do zbioru miejsc pamięci można zaliczyć: miejsca geograficzne i architektoniczne, autentyczne i legendarne postaci, pieśni, hasła, symbole, dzieła literackie, święta, obrzędy, czy też wydarzenia ${ }^{27}$. Tak interpretowane miejsca pamięci są swoistymi magazynami pamięci, z których czerpać może koncepcja wychowania obywatelskiego, mająca za zadanie zachęcić jednostkę do podmiotowości polegającej na „(...) formułowaniu się dla czegoś, a nie przeciw czemuś" 28 .

Miejsca pamięci nie tylko umożliwiają bezpośrednie odczuwanie i spotkanie z historią, kulturą i szeroko rozumianym Innym ${ }^{29}$ - co uczy tolerancji i empatii, ale również pozwalają na odniesienia do rodzimego/lokalnego dziedzictwa, które parafrazując słowa Jana Pawła II nie musi ograniczać, ale może ułatwić rozumienie i akceptację innych, torować drogę do uczestnictwa „(...) w sytuacji wielkiej rodziny ludzkości"30. Miejsca pamięci mogą stanowić impuls do międzykulturowego dialogu wolnego od uprzedzeń i stereotypów etnicznych, opartego na zasadach wymiany wartości i gotowości do zaakceptowania odmienności ${ }^{31}$. Co ważne, miejsca pamięci umożliwiają podejmowanie prób wielopłaszczyznowego spojrzenia na fakt historyczny: z perspektywy osób, które dane miejsce upamiętnia; z punktu widzenia jednostek upamiętniających - odpowiedzialnych za formę i poniekąd treść miejsca oraz człowieka współczesnego - odbiorcy ${ }^{32}$. Miejsce pamięci jest mianownikiem, w którym spotykają się różnorodne interpretacje

${ }^{25}$ T. Kranz, Edukacja historyczna w miejscach pamięci. Zarys problematyki, Lublin 2009, s. 38.

${ }^{26}$ B. Siemieniecki, Wstęp do pedagogiki kognitywistycznej, Torun 2010, s. 27-28.

27 J. Górska, Lenino - zapomniane miejsce pamięci narodowej, [w:] Miejsca pamięci w edukacji historycznej, s. 184.

${ }^{28}$ B. Wagner, Przecież stamtąd wyszliście - to także element europejskiej tradycji, [w:] tamże, s. 13.

${ }^{29}$ W. Panas, Brama, [w:] Pamięć. Miejsce. Obecność. Wspótczesne refleksje nad kultura i ich implikacje pedagogiczne, red. J.P. Hudzik, J. Mizińska, Lublin 1997 s. 22.

${ }^{30}$ K. Maliszewski, Z dziejów staropolskiej kultury i cywilizacji, Fundacja "Servire Veritati", Lublin 2010, s. 24.

31 T. Kranz, Edukacja historyczna w miejscach pamięci, s. 62; W. Theiss, Góra Kalwaria/Ger: pejzaż asocjacyjny (studium pamięci kulturowej miejsca), [w:] Pedagogika miejsca, red. M. Mendel, Wrocław 2006, s. 71.

32 A. Ziębińska-Witek, http://jazon.hist.uj.edu.pl/zjazd/materialy/ziebinska.pdf, [dostęp: 17.11.2011]. 
dokonywane przez ludzi z różnych grup społecznych, pokoleń, narodowości, co w konsekwencji może pomóc zrozumieć jednostce heterogeniczność i kontekstualność świata oraz konieczność weryfikacji docierających do niej informacji, które w umiejętny sposób należy pozyskiwać z różnych źródeł33.

Miejsca pamięci poprzez zakorzenienie $\mathrm{w}$ przeszłości inicjują myślenie przyczynowo-skutkowe oraz uczą odpowiedzialności za własne czyny. Jest to bardzo ważne, ponieważ

(...) człowiek pozbawiony zaplecza tradycji, bez reszty pogrążony w teraźniejszości, nastawiony wyłącznie aktualistycznie, nie będzie w stanie rozsądnie zaplanować (ani nawet wyobrazić sobie) przyszłości $(\ldots)^{34}$.

Obcowanie z miejscem pamięci może zainspirować jednostkę do myślenia historycznego, które ułatwia analizowanie faktów historycznych, a także rozpatrywać współczesne wydarzania w szerszej perspektywie czasowej, z uwzględnieniem kontekstu dziejowego ${ }^{35}$. Gdyż, jak słusznie zauważa Norman Davies,

(...) teraźniejszość jest wytworem przeszłości, a przeszłość stanie się kontynuacją teraźniejszości. (...) Nikt nie może zacząć rozważać spraw mających nadejść, jeśli żywo nie zachowa w pamięci spraw przeszłych ${ }^{36}$.

\section{Potencjał miejsc pamięci w edukacji obywatelskiej}

Biorąc pod uwagę potencjał edukacyjny miejsca oraz fakt, iż może być ono rozpatrywane zarówno na poziomie sfery prywatnej, jak i publicznej, wnioskować można o możliwości wykorzystania założeń pedagogiki miejsca ze szczególnym uwzględnieniem miejsc pamięci - dotychczas wiązanych przede wszystkim z edukacją historyczną - w edukacji obywatelskiej, której zadaniem jest uświadomienie jednostce, iż „(...) nie żyje w izolacji, ma historyczną przeszłość oraz ma swoje prawa, jak i obowiązki" 37.

${ }^{33}$ D. Barwińska, Ksztatcenie w miejscach pamięci a spoteczeństwo wiedzy. Pedagogika miejsc pamięci (Gedenkstättenpädagogik), [w:] Nauczyciel andragog w społeczeństwie wiedzy, red. W. Horyń, J. Maciejewski, Wrocław2007, s. 261; A. Naumiuk, Edukacja obywatelska, [w:] Encyklopedia pedagogiczna XXI wieku, red. T. Pilch, Warszawa 2003, s. 113.

34 T. Szkołut, Pamięć kultury a tożsamość człowieka ponowoczesnego, [w:] Pamieć. Miejsce. Obecność, s. 4.

35 T. Kranz, Edukacja historyczna w miejscach pamięci, s. 62.

36 N. Davies, Boże igrzysko. Historia Polski, Kraków 2006, s. 1140.

${ }_{37}$ M. Cylkowska-Nowak, Edukacja obywatelska w szkołach Wielkiej Brytanii, Francji i Polski, [w:] Wychowanie obywatelskie. Studium teoretyczne, s. 171. 
Miejsca pamięci, które są znakomitymi impulsami multikulturowych dyskusji opartych na zasadach merytorycznego dialogu ${ }^{38}$, mogą inspirować rozwój kompetencji obywatelskich. Mogą pomóc współczesnemu człowiekowi w wypracowaniu poczucia wspólnotowości. Stwarzają warunki do wyposażenia jednostki w zdolność krytycznej oceny natłoku docierających do niej informacji, bez której niemożliwe jest podejmowanie obiektywnych decyzji39. Miejsca pamięci sprzyjają także kształtowaniu odpowiedzialności za dobro wspólne i akceptacji szeroko rozumianej odmienności.

Edukacja obywatelska oparta na miejscu pamięci wpisuje się w postulowaną przez Zbyszko Melosika koncepcję wychowania obywatelskiego, która „(..) nie rezygnując z wartości narodowych i państwowych, potrafiłaby jednak umieścić je w kontekście (...) globalnych tendencji kulturowych"40. Może ona stymulować człowieka do efektywnego funkcjonowania w rzeczywistości przesyconej pluralizmem informacyjnym, $\mathrm{w}$ heterogenicznym świecie praktycznie bez granic, w którym zaobserwować można nasilające się procesy „(...) demontażu, destrukcji, rozbicia tradycyjnych, jednolitych kulturowo wzorów, zasad, orientacji aksjologicznych oraz stylów działania"41.

Dorota Barwińska podkreśla, iż zajmowanie się problematyką edukacyjnego potencjału miejsc pamięci

oznacza konieczność wiązania wiedzy historycznej, społecznej, etycznej dotyczącej tego, co było, jest i co może być, mówienia o świecie wartości i antywartości, refleksji nad przyszłością, z zarazem działaniem na rzecz przyszłości, zajmowania się przedstawicielami różnych narodów, religii i tradycji. Kształcenie $\mathrm{w}$ miejscach pamięci związane jest ściśle z przeszłością, od której nie sposób uciec, która okazać się może jednak pomocna. Ta pomoc wyjaśnia "skąd przychodzimy i dokąd zmierzamy”, ale także mówi o tym jakie są bariery i przeszkody na tej drodze i co ułatwia ich pokonywanie ${ }^{42}$.

38 T. Kranz, Edukacja historyczna w miejscach pamięci, s. 69.

${ }^{39}$ Z. Bauman, Globalizacja. I co z tego dla ludzi wynika, Warszawa 2000, s. 23; M. Hoszowska, Pamięć, historia i edukacja szkolna, [w:] Miejsca pamięci w edukacji historycznej, s. 20; P. Kawiecki, Postmodernizm jako element posymbolicznej "pauzy” kultury w fazie stabilizacji, [w:] Pamięć. Miejsce. Obecność, s. 140; S. Morawski, Pare refleksji o tradycji i mitologii, [w:] Pamięć. Miejsce. Obecność, s. 29.

40 Z. Melosik, Obywatelstwo, czas (historia) i przestrzeń (geografia), [w:] Wychowanie obywatelskie, s. 65.

${ }^{41}$ W. Dróżka, Orientacje aksjologiczne i style działania nauczycieli. Między tradycja a nowymi wyzwaniami, [w:] Pedagogika u progu trzeciego tysiaclecia, red. A. Nalaskowski, K. Rubacha, Toruń 2001, s. 183.

${ }^{42}$ D. Barwińska, Kształcenie w miejscach pamięci a społeczeństwo wiedzy, s. 267. 
Miejsca pamięci mają zatem potencjał edukacyjny, którego nie należy zaprzepaścić, ale w umiejętny sposób wykorzystać w celu kształtowania kompetencji obywatelskich. Przede wszystkim są one punktem, w którym dochodzi do zetknięcia indywidualnych interpretacji ze znaczeniami wypracowanymi przez zbiorowość. Ukazana właściwość pozwala na realizację jednego z podstawowych celów edukacji obywatelskiej, którym jest „(...) pogodzenie rozwoju osobowego z kształceniem postaw pożądanych z punktu widzenia społeczeństwa" 43 . Miejsca pamięci są nośnikami pamięci kulturowej, która oscyluje wokół wartości uniwersalnych, przez co jest odpowiednim punktem wyjścia do prowadzenia dialogu pozbawionego agresji i zmierzającego do wypracowania wspólnych wniosków. A zatem, miejsca pamięci sprzyjają wymianie poglądów opartej na respektowaniu dziedzictwa innych kultur, empatii i kulturze wzajemnej akceptacji, która może pomóc w zachęceniu jednostki do działań o charakterze utylitarnym i uczestnictwa w życiu zbiorowości. Natomiast, rozumienie miejsc pamięci bazujące na wiedzy historycznej i związanie z poznaniem racjonalnym uczy szacunku do prawdy, który powinien stanowić fundamentalną wartość $\mathrm{w}$ procesie budowania społeczeństwa obywatelskiego ${ }^{44}$.

Prawidłowo prowadzona edukacja obywatelska w miejscach pamięci, oparta na metodach aktywizujących i uczeniu się w działaniu, może zaowocować przygotowaniem jednostki do wydajnego funkcjonowania „w demokracji i dla demokracji" ${ }^{45}$. Jednakże osoby, które podejmą się tego zadania nie mogą zapominać, iż cechujący się epizodycznością i emocjonalnością proces edukacyjny $\mathrm{w}$ miejscach pamięci nastawiony na uczenie się może również przynieść odwrotny skutek od zamierzonego. Konsekwencją zetknięcia $\mathrm{z}$ miejscem pamięci może być zmiana lub wzmocnienie uczuć, wyobrażeń, doświadczeń i postaw o charakterze pozytywnym - powszechnie akceptowalnych społecznie, ale również „(..) może (...) dojść do wzmocnienia dotychczasowych uprzedzenn" 46 . Miejsca pamięci są nierozerwalnie związane $\mathrm{z}$ wiedzą faktograficzną, informacjami o charakterze racjonalistycznym, ale oddziałują także na sferę afektywną i nie sposób jednoznacznie przewidzieć, jakie uczucia i wrażenia wywołają $\mathrm{w}$ jednostkach obcujących z nimi.

${ }^{43}$ T. Kranz, Edukacja historyczna w miejscach pamięci, s. 60.

${ }^{44}$ B. Siemieniecki, Wstęp do pedagogiki kognitywistycznej, s. 8.

${ }^{45}$ D. Kubiak-Pokrzywniak, Model obywatela w wybranych koncepcjach zachodniej myśli pedagogicznej, [w:] Wychowanie obywatelskie, s. 237.

46 T. Kranz, Edukacja historyczna w miejscach pamięci, s. 64-67. 


\section{BIBLIOGRAFIA}

Barwińska D., Kształcenie w miejscach pamięci a społeczeństwo wiedzy. Pedagogika miejsc pamięci (Gedenkstättenpädagogik), [w:] Nauczyciel andragog w społeczeństwie wiedzy, red. W. Horyń, J. Maciejewski, Wydawnictwo Uniwersytetu Wrocławskiego, Wrocław 2007.

Bauman Z., Globalizacja. I co z tego dla ludzi wynika, Państwowy Instytut Wydawniczy, Warszawa 2000.

Bauman Z., Tożsamość ze sklepu. Tożsamość ze spiżarni, [w:] Kultura popularna i (re)konstrukcje tożsamości, red. A. Gromkowska-Melosik, Wyższa Szkoła Humanistyczna, Poznań - Leszno 2007.

Bauman Z., Więc będzie wojna? "Gazeta Wyborcza” z 14-15 kwietnia 2012.

Cybal-Michalska A., Ideologia konsumpcji, wirtualna rzeczywistość i społeczeństwo, [w:] Kultura popularna $i$ (re)konstrukcje tożsamości, red. A. Gromkowska-Melosik, Wyższa Szkoła Humanistyczna, Poznań - Leszno 2007.

Cylkowska-Nowak M., Edukacja obywatelska w szkołach Wielkiej Brytanii, Francji i Polski, [w:] Wychowanie obywatelskie. Studium teoretyczne, porównawcze i empiryczne, red. Z. Melosik, K. Przyszczypkowski, Wydawnictwo Edytor, Torun - Poznań 1998.

Davies N., Boże igrzysko. Historia Polski, Wydawnictwo Znak, Kraków 2006.

Dróżka W., Orientacje aksjologiczne i style działania nauczycieli. Między tradycja a nowymi wyzwaniami, [w:] Pedagogika u progu trzeciego tysiaclecia, red. A. Nalaskowski, K. Rubacha, Wydawnictwo Uniwersytetu Mikołaja Kopernika, Torun 2001.

Giddens A., Nowoczesność i tożsamość. "Ja" i społeczeństwo w epoce późnej nowoczesności, Wydawnictwo Naukowe PWN, Warszawa 2001.

Górska J., Lenino - zapomniane miejsce pamięci narodowej, [w:] Miejsca pamięci w edukacji historycznej. Zbiór studiów, red. S. Roszak, M. Strzelecka, A. Wieczorek, Stowarzyszenie Oświatowców Polskich, Torun 2009.

Grunewald D.A., The Best of Both Worlds: A Critical Pedagogy of Place, Educational Researcher, 2003, 4(32).

Hall E.T., Ukryty wymiar, Państwowy Instytut Wydawniczy, Warszawa 1978.

Hoszowska M., Pamięć, historia i edukacja szkolna, [w:] Miejsca pamięci w edukacji historycznej. Zbiór studiów, red. S. Roszak, M. Strzelecka, A. Wieczorek, Stowarzyszenie Oświatowców Polskich, Torun 2009.

Jaworski M., Kultura popularna i refleksyjny projekt tożsamości, [w:] Kultura popularna $i$ (re)konstrukcje tożsamości, red. A. Gromkowska-Melosik, Wyższa Szkoła Humanistyczna, Poznań - Leszno 2007.

Jayanandhan S.R., John Dewey and a pedagogy of place, Philosophical Studies in Education, 2009, 40.

Kawiecki P., Postmodernizm jako element posymbolicznej "pauzy" kultury w fazie stabilizacji, [w:] Pamięć. Miejsce. Obecność. Wspótczesne refleksje nad kultura i ich implikacje pedagogiczne, red. J.P. Hudzik, J. Mizińska, Wydawnictwo Uniwersytetu Marii CurieSkłodowskiej, Lublin 1997.

Kranz T., Edukacja historyczna w miejscach pamięci. Zarys problematyki, Państwowe Muzeum na Majdanku, Lublin 2009.

Kubiak-Pokrzywniak D., Model obywatela w wybranych koncepcjach zachodniej myśli pedagogicznej, [w:] Wychowanie obywatelskie. Studium teoretyczne, porównawcze i empiryczne, red. Z. Melosik, K. Przyszczypkowski, Wydawnictwo Edytor, Torun - Poznań 1998. 
Kurantowicz E., Uczenie się dorostych przez „biografię miejsca”, Dyskursy Młodych Andragogów, 2003, 4.

Kwiatkowska H., Czas, miejsce, przestrzeń - zaniedbane kategorie pedagogiczne, [w:] Pedagogika u progu trzeciego tysiaclecia, red. A. Nalaskowski, K. Rubacha, Wydawnictwo Uniwersytetu Mikołaja Kopernika, Torun 2001.

Maliszewski K., Z dziejów staropolskiej kultury i cywilizacji, Fundacja "Servire Veritati", Instytut Edukacji Narodowej, Lublin 2010.

Melosik Z., Różnica jako (kon)tekst pedagogiczny: ponowoczesne kontrowersje, [w:] Pamięć. Miejsce. Obecność. Wspótczesne refleksje nad kultura i ich implikacje pedagogiczne, red. J.P. Hudzik, J. Mizińska, Wydawnictwo Uniwersytetu Marii Curie-Skłodowskiej, Lublin 1997.

Melosik Z., Obywatelstwo, czas (historia) i przestrzeń (geografia), [w:] Wychowanie obywatelskie. Studium teoretyczne, porównawcze i empiryczne, red. Z. Melosik, K. Przyszczypkowski, Wydawnictwo Edytor, Torun - Poznań 1998.

Melosik Z., Kultura instant - paradoksy pop-tożsamości, [w:] Pedagogika u progu trzeciego tysiaclecia, red. A. Nalaskowski, K. Rubacha, Wydawnictwo Uniwersytetu Mikołaja Kopernika, Torun 2001.

Mendel M., Pedagogika miejsca i animacja na miejsce wrażliwa, [w:] Pedagogika miejsca, red. M. Mendel, Wydawnictwo Naukowe Dolnośląskiej Szkoły Wyższej Edukacji TWP, Wrocław 2006.

Mendel M., Wstęp, [w:] Pedagogika miejsca, red. M. Mendel, Wydawnictwo Naukowe Dolnośląskiej Szkoły Wyższej Edukacji TWP, Wrocław 2006.

Morawski S., Parę refleksji o tradycji i mitologii, [w:] Pamięć. Miejsce. Obecność. Wspótczesne refleksje nad kultura $i$ ich implikacje pedagogiczne, red. J.P. Hudzik, J. Mizińska, Wydawnictwo Uniwersytetu Marii Curie-Skłodowskiej, Lublin 1997.

Nalaskowski A., Przestrzenie i miejsca szkoty, Oficyna Wydawnicza Impuls, Kraków 2002.

Naumiuk A., Edukacja obywatelska, [w:] Encyklopedia pedagogiczna XXI wieku, red. T. Pilch, Wydawnictwo Akademickie Żak, Warszawa 2003.

Panas W., Brama, [w:] Pamięć. Miejsce. Obecność. Wspótczesne refleksje nad kultura i ich implikacje pedagogiczne, red. J.P. Hudzik, J. Mizińska, Wydawnictwo Uniwersytetu Marii Curie-Skłodowskiej, Lublin 1997.

Pinkiewicz-Gara B., Twierdza kłodzka - miejsce pamięci, [w:] Miejsca pamięci w edukacji historycznej. Zbiór studiów, red. S. Roszak, M. Strzelecka, A. Wieczorek, Stowarzyszenie Oświatowców Polskich, Toruń 2009.

Przyszczypkowski K., Postawy obywatelskie Polaków. Studium empiryczne, [w:] Wychowanie obywatelskie. Studium teoretyczne, porównawcze i empiryczne, red. Z. Melosik, K. Przyszczypkowski, Wydawnictwo Edytor, Torun - Poznań 1998.

Roszak S., O miejscach pamięci, [w:] Miejsca pamięci w edukacji historycznej. Zbiór studiów, red. S. Roszak, M. Strzelecka, A. Wieczorek, Stowarzyszenie Oświatowców Polskich, Toruń 2009.

Sagan I., Ludzie i ich miejsca w geografii postmodernistycznej, [w:] Różnica, tożsamość, edukacja. Szkice z pogranicza, red. T. Szkudlarek, Oficyna Wydawnicza Impuls, Kraków 1995.

Schulz R., Wykłady z pedagogiki ogólnej. Perspektywy światopogladowe w wychowaniu, Wydawnictwo Uniwersytetu Mikołaja Kopernika, Torun 2003.

Siemieniecki B., Wstęp do pedagogiki kognitywistycznej, Wydawnictwo Adam Marszałek, Toruń 2010. 
Simlat M., Edukacja obywatelska jako ksztattowanie kompetencji obywatelskich, [w:] Edukacja w społeczeństwie obywatelskim i system wartości, red. J. Żebrowski, Gdańskie Towarzystwo Naukowe, Gdańsk 1996.

Solarczyk-Szwec H., Edukacja obywatelska młodzieży i dorostych wobec przemocy politycznej działania na pograniczu aktywności społecznej, oświatowej i kulturalnej, Rocznik Andragogiczny, 2007.

Szacki J., Społeczeństwo obywatelskie, Przeglą Polityczny, 1996, 31.

Szkołut T., Pamięć kultury a tożsamość człowieka ponowoczesnego, [w:] Pamięć. Miejsce. Obecność. Współczesne refleksje nad kultura $i$ ich implikacje pedagogiczne, red. J.P. Hudzik, J. Mizińska, Wydawnictwo Uniwersytetu Marii Curie-Skłodowskiej, Lublin 1997.

Theiss W., Góra Kalwaria/Ger: pejzaż asocjacyjny (studium pamięci kulturowej miejsca), [w:] Pedagogika miejsca, red. M. Mendel, Wydawnictwo Naukowe Dolnośląskiej Szkoły Wyższej Edukacji TWP, Wrocław 2006.

Tuan Y., Przestrzeń i miejsce, Państwowy Instytut Wydawniczy, Warszawa 1987.

Unger P., Tradycja też jest miejscem pamięci, [w:] Miejsca pamięci w edukacji historycznej. Zbiór studiów, red. S. Roszak, M. Strzelecka, A. Wieczorek, Stowarzyszenie Oświatowców Polskich, Torun 2009.

Wagner B., Przecież stamtąd wyszliście - to także element europejskiej tradycji, [w:] Miejsca pamięci w edukacji historycznej. Zbiór studiów, red. S. Roszak, M. Strzelecka, A. Wieczorek, Stowarzyszenie Oświatowców Polskich, Torun 2009.

Zielińska M., Edukacja dorostych imigrantów na Islandii w świetle pedagogiki miejsca, Rocznik Andragogiczny, 2009.

\section{Netografia}

Knapp C.L., Woodhouse J.L., Place - Based Curriculum and Instruction: Outdoor and Environmental Education Approaches, http://www.ericdigests.org/2001-3/place.htm [dostęp: 17.11.2011].

Ziębińska-Witek A., Wizualizacje pamięci - upamiętnianie Zagłady w muzeach, http://jazon. hist.uj.edu.pl/zjazd/materialy/ziebinska.pdf [dostęp: 19.11.2011]. 